Original Research Paper

\title{
Pemetaan Jalur Evakuasi Dan Titik Kumpul Dalam Upaya Mewujudkan Desa Pijot Yang Tanggap Bencana
}

\author{
Siti Maryam Ulfa ${ }^{1}$, Dipo Ario Kusuma ${ }^{2}$, Arni Emiza Febrianti ${ }^{3}$, Rosiatul Ismi ${ }^{4}$, Siti Nuriah ${ }^{5}$, Nurul Zainiyah ${ }^{6}$, \\ Rina Nuranjanisa ${ }^{7}$, Soraya Rosanti ${ }^{8}$, Ni Komang Eva Yuniasih ${ }^{9}$, Tiara Hesti Amanda ${ }^{10}$, Mila Andara ${ }^{11}$, Lalu \\ Sumardi ${ }^{12^{*}}$
}

Fakultas Keguruan dan Ilmu Pendidikan, Universitas Mataram, Mataram, Indonesia

https://doi.org/10.29303/jpmpi.v3i2.1319

Sitasi: Ulfa, S. M., Kusuma, D. A., Febrianti, A. E., Ismi, R., Nuriah, S., Zainiyah, N., Nuranjanisa, R., Rosanti, S., Yuniasih, N. K. E., Amanda, T. H., Andara, M \& Sumardi, L. (2022). Pemetaan Jalur Evakuasi Dan Titik Kumpul Dalam Upaya Mewujudkan Desa Pijot Yang Tanggap Bencana. Jurnal Pengabdian Magister Pendidikan IPA, 5(1)

\section{Article history}

Received: 11 Januari 2022

Revised: 01 Februari 2022

Accepted: 07 Februari 2022

*Corresponding Author:

Author A, Institute/

Organization Name, City

Name, Country Name;

Email: support@thescipub.com

\begin{abstract}
Bencana merupakan suatu peristiwa atau rangkaian kejadian yang mengakibatkan penderitaan manusia, kerugian harta benda, kerusakan lingkungan, sarana dan prasarana serta dapat menimbulkan gangguan terhadap tata kehidupan dan penghidupan masyarakat. Desa Pijot merupakan salah satu daerah yang berada di pesisir pantai pulau Lombok dengan tinggi tempat dari permukaan laut sebesar 500 mdpl dan tingkat curah hujan 491 $\mathrm{mm}$, membuat daerah ini seringkali terdampak bencana. Hal ini tentu menjadi suatu hal yang seharusnya patut diwaspadai, mengingat bencana sewaktu-waktu bisa saja terjadi, sehingga perlu adanya mitigasi bencana, yaitu visualisasi/pemetaan jalur evakuasi bencana. Tujuan yang diharapkan dari kegiatan pengabdian ini yaitu adanya jalur evakuasi, yang dikhususkan untuk bencana banjir rob, gempa dan tsunami, serta diharapkan jalur evakuasi menjadi sarana terbaik yang bisa memudahkan masyarakat dalam mengevakuasi diri saat terjadi bencana.
\end{abstract}

Keywords: Bencana, Mitigasi, Jalur Evakuasi, Titik Kumpul

\section{Pendahuluan}

$\mathrm{I}_{\mathrm{y}}^{\mathrm{n}}$ donesia adalah salah satu negara di kawasan Asia yang rawan terhadap bencana atau merupakan negara dengan potensi bahaya (hazard potency) yang sangat tinggi. Secara geografis, geologis, dan demografis wilayah Indonesia memungkinkan terjadinya bencana, karena terletak pada pertemuan tiga lempeng dunia yang masih aktif, sehingga pergerakan lempeng bumi tersebut memungkinkan terjadinya bencana. Sutopo Purwo Nugroho (dalam Hastuti, 2016), menyebutkan bahwa bencana banjir, bencana sedimen, gempa bumi dan tsunami merupakan empat karakter bencana yang dominan terjadi di Indonesia. Data tahun 2015 bahwa sebanyak 1.681 kejadian bencana, yang menyebabkan 259 orang tewas, 1,23 juta mengungsi, 25.192 unit rumah rusak (5.180 rusak berat, 3.760 rusak sedang, 16.252 rusak ringan), 498 unit fasum rusak. Lebih dari $95 \%$ merupakan bencana hidrometereologi. Data tersebut juga memberikan penegasan bahwa Indonesia adalah negara darurat bencana.

Menurut Sudibyakto (2011), bencana merupakan suatu peristiwa atau rangkaian kejadian yang mengakibatkan penderitaan manusia, kerugian harta benda, kerusakan lingkungan, sarana dan prasarana serta dapat menimbulkan gangguan terhadap tata kehidupan dan penghidupan 
masyarakat. Bencana lingkungan (environmental disaster) telah terbukti sebagai salah satu ancaman serius di Indonesia yang gejalanya sedang meningkat baik frekuensi kejadiannya maupun wilayah sebarannya. Bencana alam seperti kekeringan, banjir, gempa bumi dan tsunami sangat mungkin dapat memicu timbulnya bencana lingkungan berkelanjutan (sustainable development). Bencana dapat menyebabkan kerugian baik moril maupun materil bagi masyarakat korban, menyebabkan degradasi mental atau menimbulkan trauma, bahkan sampai menimbulkan adanya korban jiwa.

Setiap wilayah Indonesia masing-masing memiliki daerah yang rawan bencana. Salah satu daerah yang rawan bencana adalah Pulau Lombok, Nusa Tenggara Barat. Pulau Lombok merupakan salah satu pulau terbesar di Provinsi Nusa Tenggara Barat (NTB) juga memiliki tingkat kerawanan yang tinggi terhadap bencana. Hal ini dikarenakan bagian selatan pulau Lombok berhadapan langsung dengan Samudra Hindia yang merupakan pertemuan dua lempeng yaitu lempeng Benua Asia dan lempeng Benua Australia (Santoso, 2019). Salah satu daerah di pulau Lombok yaitu Desa Pijot.

Desa Pijot secara administratif merupakan Desa Induk dan telah melakukan pemekaran menjadi dua Desa yaitu Pijot Induk dan Pijot Utara, serta merupakan salah satu dari 15 Desa di Kecamatan Keruak yang teletak pada radius 3 Kilometer sebelah Timur ibu kota Kecamatan Keruak.

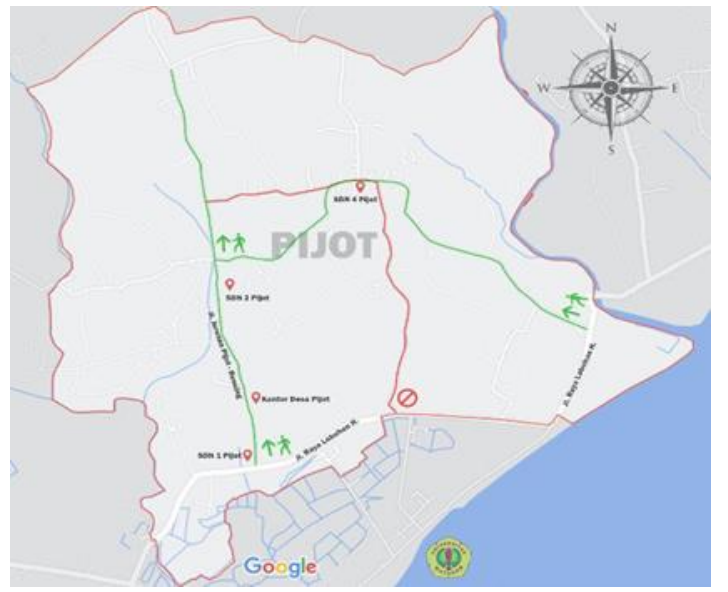

Gambar 1. Lokasi Desa Pijot

Desa Pijot memiliki luas wilayah 715 hektar, tersebar pada 8 Kepala Dusun, yaitu Dusun Pijot Selatan, Dusun Permai Indah, Dusun Pemban Pijot, Dusun Pemban Aji, Dusun Larangan, Dusun Bendera Baru, Dusun Padak Selatan dan Dusun Padak Timur Sebelah Utara Desa Pijot berbatasan langsung dengan Desa Menceh, sebelah Timur berbatasan dengan Desa Tanjung Luar dan Ketapang Raya, sebelah Selatan berbatasan dengan Desa Ketangge Jaraeng, dan sebelah Barat berbatasan dengan desa Pijot Utara dan Menceh dan (RPJMdes, 2021).

Jumlah penduduk di Desa Pijot sebanyak 6113 jiwa. Jumlah penduduk yang banyak dan letak daerah yang berada di pesisir pantai dengan tinggi tempat dari permukaan laut sebesar 500 mdpl dan tingkat curah hujan $491 \mathrm{~mm}$ (RPJMDes, 2021), membuat daerah ini juga seringkali terdampak bencana. Desa Pijot sering menghadapi permasalahan lingkungan yang serius, seperti sering terjadinya banjir rob yang sewaktu-waktu bisa melanda pemukiman warga, terjadinya abrasi, dan penyusutan air asin ke arah daratan, gempa bumi serta memungkinkan potensi tsunami terjadi. Ini tentu menjadi suatu hal yang seharusnya patut diwaspadai, mengingat bencana sewaktu-waktu bisa saja terjadi, sehingga perlu adanya kesiapan masyarakat untuk menghadapi kejadian saat bencana, seperti pengetahuan awal terkait bencana, daerah potensi bencana, sarana dan prasarana yang memungkinkan untuk melakukan evakuasi diri saat terjadi bencana dan banyak hal lain yang patut menjadi perhatian.

Berdasarkan hal tersebut, penulis menawarkan program pengabdian masyarakat terkait dengan kesiapsiagaan bencana yang terjadi di Desa Pijot, yaitu Visualisasi/Pemetaan jalur evakuasi bencana. Jalur evakuasi merupakan salah satu sarana yang harus dipersiapkan dalam mendukung kesiapsiagaan bencana. Manfaat yang diharapkan dari kegiatan pengabdian ini yaitu terpetakannya jalur evakuasi, yang dikhususkan untuk bencana banjir rob dan tsunami, serta diharapkan jalur evakuasi menjadi sarana terbaik yang bisa memudahkan masyarakat dalam mengevakuasi diri saat terjadi bencana.

\section{Metode}

\section{Tempat dan Waktu}

Kegiatan pengabdian ini dilaksanakan di Desa Pijot, Kecamatan Keruak, Kabupaten Lombok Timur, Provinsi Nusa Tenggara Barat. Proses kegiatan dilaksanakan selama kegiatan Kuliah Kerja Partisipatif (KKN) dari November 2021-Januari 2022.

\section{Khalayak Sasaran}


Sasaran dalam kegiatan pengabdian ini yaitu semua masyarakat Desa Pijot, yang tersebar dalam 8 dusun, yaitu Dusun Pijot Selatan, Dusun Permai Indah, Dusun Pemban Pijot, Dusun Pemban Aji, Dusun Larangan, Dusun Bendera Baru, Dusun Padak Selatan dan Dusun Padak Timur Sebelah Utara Desa Pijot berbatasan langsung dengan Desa Menceh, sebelah Timur berbatasan dengan Desa Tanjung Luar dan Ketapang Raya, sebelah Selatan berbatasan dengan Desa Ketangge Jaraeng, dan sebelah Barat berbatasan dengan desa Pijot Utara dan Menceh.

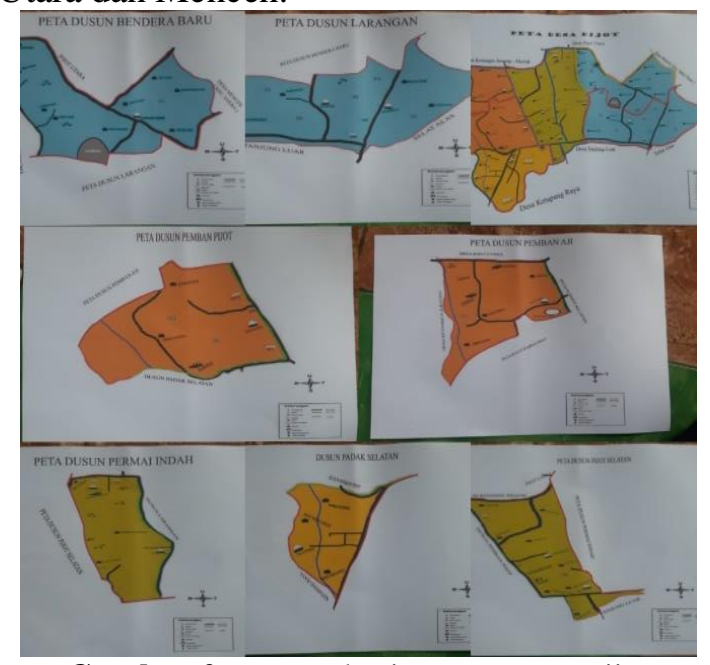

Gambar 2. Peta Lokasi Dusun Desa Pijot

3. Metode Pengabdian

Penyusunan rencana evakuasi bencana di laksanakan dengan tiga tahap yaitu tahap diskusi dengan kelompok, tahap observasi dan wawancara, tahap pemetaan lokasi, serta tahap visualisasi.

a. Diskusi dengan Anggota Kelompok

Tahap pertama yakni tahap diskusi ini dengan anggota kelompok tim pengabdi. Diskusi dilakukan untuk membicarakan terkait dengan program pengabdian yang mau dilaksanakan, mendiskusikan kesepakatan pemetaan waktu untuk melakukan observasi dan wawancara, pemetaan lokasi, pengeksekusian program pengabdian dengan pembelian bahan yang dibutuhkan sampai tahap visualisasi dan pembuatan.

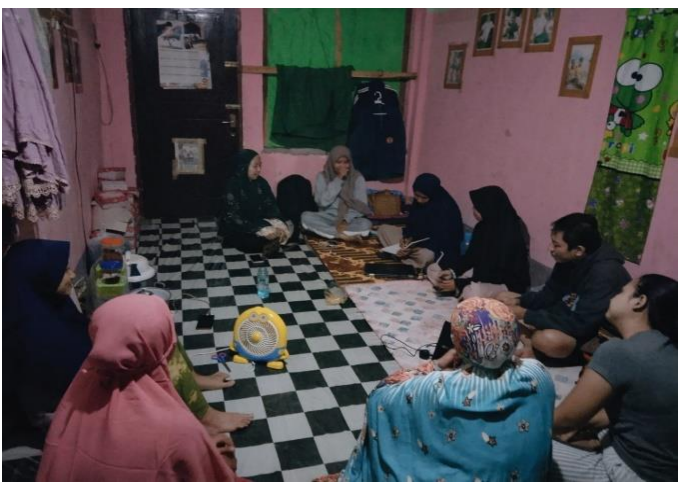

Gambar 3. Tahap Diskusi Tim Pengabdi

b. Tahap Observasi dan Wawancara

Tahap kedua yang dilakukan oleh tim pengabdi, yakni melakukan kegiatan observasi dan wawancara. Pada tahap ini dilakukan observasi atau pengamatan langsung lokasi di seluruh wilayah desa Pijot untuk mengetahui ada atau tidaknya daerah titik kumpul dan jalur evakuasi yang tersedia di desa. Tahap observasi juga dilakukan untuk mengetahui daerah yang rawan bencana, serta lokasi yang memungkinkan untuk dijadikan titik kumpul dan jalur evakuasi. Selain dengan tahap observasi, dilakukan juga tahapan wawancara pada perangkat desa, khususnya Kepala Desa Pijot untuk mendapatkan data yang dibutukan.

c. Tahap Pemetaan Lokasi

Pada tahap ini dilakukan pemetaan lokasi yang akan dijadikan lokasi titik kumpul dan jalan-jalan yang bisa diakses untuk dijadikan jalur evakuasi. Dalam pemetaan lokasi dilakukan beberapa pertimbangan, termasuk pertimbangan mudahnya akses jalan, letak daerah yang memungkinkan dijadikan daerah evakuasi bencana (tinggi rendahnya lokasi) dan pertimbangan-pertimbangan lainnya.

d. Tahap Visualisasi

Setelah melakukan pemetaan dan penentuan lokasi titik kumpul dan jalur evakuasi bencana (dalam hal ini dikhususnya untuk bencana banjir dan tsunami), maka dilakukan visualisasi kegiatan pengabdian, yaitu pembuatan plang jalur evakuasi dan titik kumpul. 


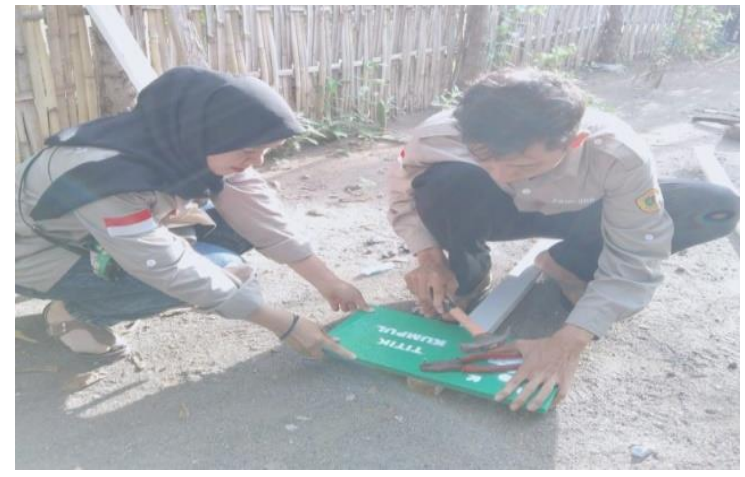

Gambar 4. Visualisasi Jalur Evakuasi dan Titik Kumpul

e. Pemasangan

Tahap terakhir yang dilakukan oleh tim pengabdi adalah publikasi, yakni pemasangan plang jalur evakuasi dan titik kumpul yang telah dibuat.

\section{Indikator Keberhasilan}

Setelah melakukan seluruh tahapan kegiatan, maka dalam pelaksanaan kegiatan pengabdian, maka perlu diukur keterlaksanaan dan tingkat pencapaian kegiatan tahapan kegiatan yang direncanakan oleh tim pengabdi, sebagai bahan evaluasi dan perbaikan selanjutnya. Berikut indikator keberhasilan kegitan.

a. Diskusi

Pada tahapan diskusi dengan tim pengabdi, maka tim pengabdi menyepakati pemetaan waktu untuk melakukan survey, pemetaan lokasi, pengeksekusian program pengabdian dengan pembelian bahan yang dibutuhkan sampai tahap visualisasi dan pembuatan.

b. Observasi dan Wawancara

Kegiatan pada tahap ini berjalan dengan lancar, Kegiatan observasi dilakukan oleh tim pengabdi, dipandu langsung oleh sekretaris Desa Pijot. Dalam kegiatan observasi, pengabdi mendapatkan data bahwasanya di daerah Pijot hanya tersedia satu titik kumpul dan belum ada jalur evakuasi yang dibuat, sehingga ini menjadi salah satu tanda masih kurangnya mitigasi bencana di Desa Pijot. Dalam kegiatan wawancara, tim pengabdi mendapatkan data lokasi-lokasi yang bisa menjadi rekomendasi untuk lokasi titik kumpul dan pembuatan jalur evakuasi. Sehingga, dalam kegiatan ini, tim pengabdi mendapatkan banyak informasi tambahan yang bisa dijadikan rekomendasi pelaksanaan kegiatan (pembuatan jalur evakuasi dan titik kumpul). Dalam kegiatan observasi dan wawancara juga ini didapatkan data bahwa daerah-daerah yang rawan terkena bencana banjir rob dan tsunami adalah masyarakat yang tinggal di pesisir pantai di Desa Pijot.

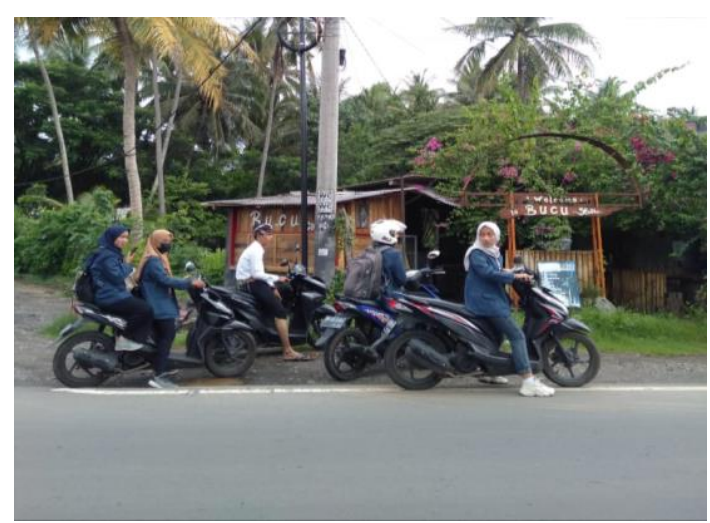

Gambar 5. Survey Lokasi Jalur Evakuasi

c. Pemetaan Lokasi

Setelah melakukan observasi dan wawancana, maka tim pengabdi menentukan atau memusatkan lokasi untuk pembuatan jalur evakuasi dan titik kumpul. Penentuan titik kumpul dan jalur evakuasi sangat penting dalam menyelamatkan warga jika terjadi bencana. Titik kumpul jika terjadi bencana dipetakan lokasinya di SDN 1 Pijot, SDN 2 Pijot dan SDN 3 Pijot. Pemetaan lokasi ini berdasarkan pertimbangan kemudahan akses jalan, letak tempat yang memungkinkan dijadikan sebagai jalur evakuasi dan titik kumpul, Kemudian titik kumpul yang ideal adalah tempat yang luas dan terbuka serta berupa dataran tinggi yang jauh dari pesisir pantai yang dapat menampung banyak orang.

d. Pembuatan Plang

Pembuatan plang jalur evakuasi dan titik kumpul dilakukan bersama tim pengabdi, plang titik kumpul yang dibuat sebanyak 2 plang, sebab di SDN 1 Pijot sudah ada plang titik kumpulnya. Sedangkan, plang jalur evakuasi yang dibuat sebanyak 4 plang.

e. Visualisasi/Pemasangan 
Setelah melakukan pembuatan plang, maka tim pengabdi melakukan pemasangan plang pada titik kumpul dan jalur lokasi yang sudah di petakan. Penanda atau pemasangan jalur evakuasi di desa pijot di buat untuk mempermudah masyarakat dalam mengevakuasi diri jika terjadi bencana. Penanda jalur evakuasi di terapkan pada beberapa lokasi. Berikut ini visualisasi titik kumpul bagi masyarakat Desa Pijot jika terjadi bencana.

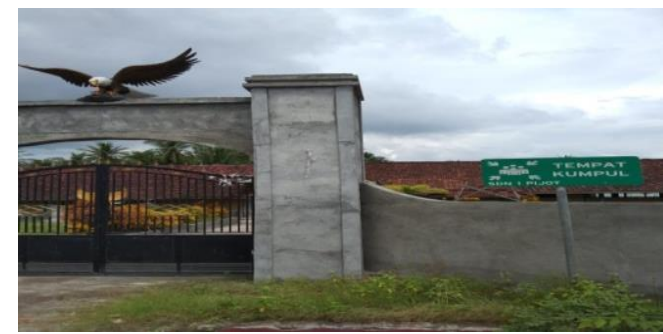

Gambar 6. Titik Kumpul SDN 1 Pijot

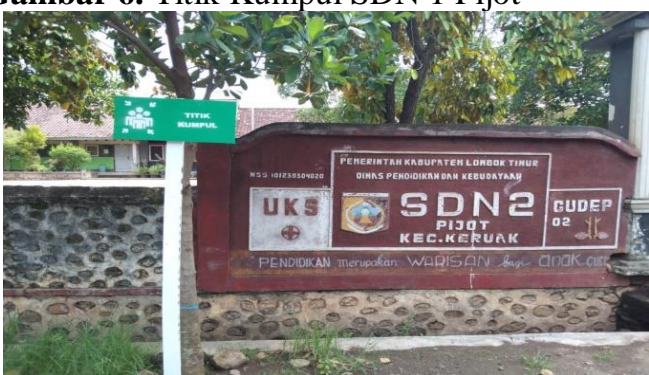

Gambar 7. Titik Kumpul SDN 2 Pijot

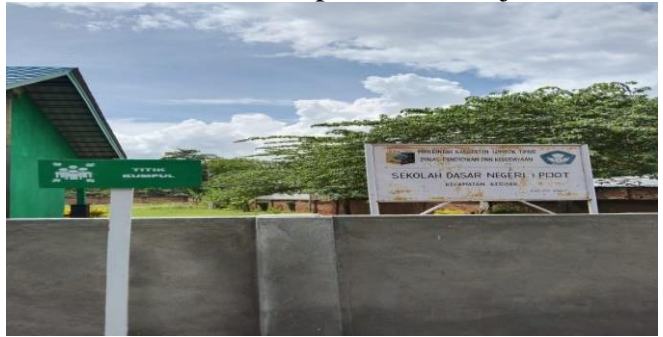

Gambar 8. Titik Kumpul SDN 3 Pijot

Setelah pemasangan plang titik kumpul, maka dilakukan pemasangan plang jalur evakuasi, berikut visualisasi kegiatan.

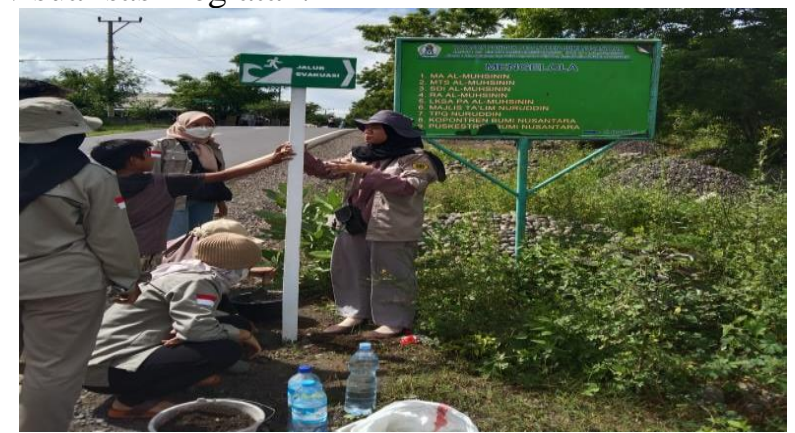

Gambar 9. Pemasangan Plang Jalur Evakuasi

\section{Kesimpulan}

Berdasarkan uraian dan seluruh data yang sudah dijabarkan maka dapat disimpulkan bahwa Desa Pijot sebagai salah satu desa pesisir pantai, dengan tinggi tempat dari permukaan laut sebesar $500 \mathrm{mdpl}$ dan tingkat curah hujan $491 \mathrm{~mm}$, yang termasuk daerah rawan bencana, Pemahaman masyarakat yang minim terkait dengan potensi bencana dan mitigasi bencana, diperlukan edukasi lebih lanjut, salah satunya menyediakan jalur evakuasi dan titik kumpul yang bisa diakses saat terjadi bencana. Kegiatan pembuatan jalur evakuasi dan titik kumpul sebagai salah satu bagian dari mitigasi bencana pada masyarakat di Desa Pijot telah berhasil di realisasikan oleh tim pengabdi. Indikator keberhasilan yang sudah dicapai dapat diukur dari sudah tersedianya lokasi titik kumpul bagi masyarakat yang ingin mengevakuasi diri saat terjadi bencana, tersedianya plang jalur evakuasi yang memberikan petunjuk kepada masyarakat saat menuju titik kumpul. Sehingga, diharapkan masyarakat desa Pijot menjadi masyarakat yang sadar dan tanggap bencana sehingga tercipta desa Pijot yang tangguh.

\section{Daftar Pustaka}

Hastuti. 2016. Peran Perempuan dalam Menghadapi Bencana di Indonesia. Geomedia, 14 (2).

Sudibyakto. 2011. Manajemen Bencana di Indonesia ke Mana?. Yogyakarta: Gadjah Mada University Press.

RPJMDes. 2021. Rencana Pembangunan Jangka Menengah Desa Pijot.

Santoso, Didik., M. Yamin., dan Muh. Mahrus. 2019. Penyuluhan tentang Mitigasi Bencana Tsunami berbasis Hutan Mangrove di Desa Ketapang Raya Kecamatan Keruak Lombok Timur. Jurnal Pengabdian Magister Pendidikan IPA, 1 (2). 